\title{
Simulation of feed restriction and fasting: Effects on animal recovery and gastrointestinal permeability in unweaned Angus-Holstein calves
}

\author{
L. Pisoni, ${ }^{1} \odot$ M. Devant, ${ }^{1 *} \oplus$ M. Blanch, ${ }^{2} \odot$ J. J. Pastor, ${ }^{2} \oplus$ and S. Marti ${ }^{1 *} \odot$ \\ ${ }^{1}$ Department of Ruminant Production, IRTA (Institut de Recerca i Tecnologies Agroalimentàries), Torre Marimon, 08140 Caldes de Montbui, \\ Barcelona, Spain \\ ${ }^{2}$ Lucta S.A., Innovation Division, UAB Research Park, Edifici Eureka, 08193 Bellaterra, Barcelona, Spain
}

\begin{abstract}
Feed restriction and fasting experienced during commercial production negatively affect unweaned calves' behavior and health status. Transportation and stays at assembly centers are the main factors generating these disorders. For this study, 20 unweaned Angus-Holstein bull calves $[44.1 \pm 2.04 \mathrm{~kg}$ of body weight $(\mathrm{BW})$ and $14.7 \pm 0.63 \mathrm{~d}$ of age ( \pm standard error)] were used to evaluate the effects of feed restriction and fasting on performance, energy status [serum concentration of glucose, $\beta$-hydroxybutyrate (BHB), and nonesterified fatty acids], and gastrointestinal permeability [serum concentration of citrulline, chromium (Cr)-EDTA, lactulose, and D-mannitol]. Calves were randomly assigned to 1 of 4 treatments that simulated the feed restrictions of an assembly center situation on one hand, and the fasting hours during transportation on the other. Treatments were as follows. Control (CT): from d -4 to -1 , calves were fed $2.5 \mathrm{~L}$ of milk replacer (MR) twice daily; concentrate and straw were offered ad libitum. Mild (MD): calves were fed only MR (d -4 to -1 ) as described for $\mathrm{CT}$, and on $\mathrm{d}-1$ calves were subjected to a 9-h feed withdrawal. Moderate (MO): calves were fed only MR (d -4 to -1 ) as described for CT and on $\mathrm{d}-1$ subjected to a $19-\mathrm{h}$ feed withdrawal. Severe (SV): calves were fed only $2.5 \mathrm{~L}$ of a rehydrating solution twice daily ( $\mathrm{d}-4$ to -1 ) and on $\mathrm{d}-1$ subjected to a 19-h feed withdrawal. From d 0 to d 42 (weaning) all calves were fed the same feeding program (MR, concentrate, and straw ad libitum). Results showed that $\mathrm{BW}$ was greater for the $\mathrm{CT}$ treatment compared with the others from d 0 to $\mathrm{d} 7$, whereas BW of SV was lesser compared with the others from $\mathrm{d}-1$ to $\mathrm{d} 7$. No differences among treatments were observed at weaning. At $\mathrm{d} 2$ concentrate intakes of $\mathrm{MD}, \mathrm{MO}$, and $\mathrm{SV}$ were lesser compared with CT. By d 4, concentrate
\end{abstract}

Received June 15, 2021.

Accepted December 1, 2021.

*Corresponding authors: maria.devant@irta.cat and sonia.marti@ irta.cat intake of SV was similar to that for $\mathrm{CT}$ and greater than MD and MO. Similarly to BW, no differences in concentrate intake among treatments were observed at weaning on d 42 of the study. At d -1 for SV and d 0 in all restricted calves, serum glucose concentration was lesser compared with CT. At d -1 and 0, nonesterified fatty acids and BHB serum concentrations were greater in the SV calves compared with the other treatments. By d 2, serum concentrations of nonesterified fatty acids, BHB, and glucose were restored to CT levels. At d -1 serum citrulline concentration was lesser in SV and greater in MD calves. The CT calves had lower serum concentrations of Cr-EDTA (d -1 and d 0), lactulose (d 0), and D-mannitol (d 0) compared with the other restricted calves. Results showed that degree of dietary restriction, type of liquid diet (MR or rehydrating solution), and fasting hours (9 vs. 19 h) affected calves' BW, concentrate intake, and serum concentration of markers indicative of energy status and gastrointestinal permeability.

Key words: calf, feed restriction, fasting, gastrointestinal permeability

\section{INTRODUCTION}

Unweaned male dairy calves are considered a byproduct of the dairy industry, and their marketing for meat production has become a common practice. These calves can be marketed and transported from their origin farms directly to their final destinations or be marketed through assembly centers before being transported to calf-rearing facilities (Pardon et al., 2014; Wilson et al., 2020).

These calves encounter many challenges during transportation due to the stress caused by commingling, mixing of animals from different origins, physical trauma, environmental conditions, handling, and deprivation of feed and water (González et al., 2012; Cooke, 2017). In addition to the transportation phase in the truck, calves spend anything from several hours to 3 to $4 \mathrm{~d}$ at assembly centers where they are usually fed only rehydrating solutions, aggravating their feed 
restriction. Overall, these conditions have been shown to negatively affect calves' health, immunological status, and energetic balance (Cernicchiaro et al., 2012; Renaud et al., 2018; Marcato et al., 2020).

Another important health parameter that can be affected by feed restriction is gastrointestinal permeability. Under normal physiological conditions, gut permeability can regulate the passage of solutes through and between adjacent intestinal cells (Hall, 1999). However, under stressful situations such as transportation or feed restriction, cortisol produced in response to stress has been shown to disrupt intestinal permeability, affecting normal digestive functions and decreasing feed intake (Lambert, 2009). If the integrity of the epithelial barrier is affected, so is its capacity to adequately regulate gut permeability. Consequently, the free passage of molecules, microorganisms, and other pathogens from the intestinal lumen to the bloodstream increases the chances of developing diseases. Among the many triggers in gastrointestinal permeability dysfunction, feed restriction has been noted as a risk factor for passage of endotoxins from the intestinal lumen to the bloodstream (Deitch et al., 1987). Several studies conducted in bovines have demonstrated that short-term (Zhang et al., 2013) or progressive (Kvidera et al., 2017) feed restriction can affect tract barrier function and generate changes in intestinal architecture.

Altogether, these situations condition calves' health status and might influence their future performance. Efforts should be made to the look for strategies to alleviate the negative effects of transportation and feed restriction. Marcato et al. (2020) have demonstrated that pre-transport feeding strategies can influence calves' health in the short term after arrival at the rearing farm. However, there is still a lack of knowledge on the influence of previous feeding regimens on gut integrity in young calves. We hypothesized that the degree of feed restriction (period where calves were fed nutrients below their nutritional requirements) and duration of fasting (period of complete absence of feed and water) during transportation and marketing negatively affects young calves' gut integrity and recovery.

Therefore, the objectives of the present study were to simulate the effects of feed restriction during marketing and fasting during transportation on calves, to evaluate their effects on performance, physiological parameters, behavior, and gastrointestinal permeability.

\section{MATERIALS AND METHODS}

\section{Animals, Treatments, and Feeding}

All calves used in this study were managed following the principles and guidelines of the Animal Care
Committee of Institut de Recerca i Tecnologia Agroalimentàries (Barcelona, Spain; RD 53/2013; project no. 10885). Calves were born at a commercial dairy farm located in Lleida, Spain (Granja San José, S.A.). At birth, they were fed $4 \mathrm{~L}$ of colostrum within the first 6 $\mathrm{h}$ after birth and $2 \mathrm{~L}$ of colostrum $12 \mathrm{~h}$ after the first colostrum feeding. All feedings were administered via esophageal tube. After colostrum consumption, calves were allocated in individual hutches and fed milk replacer (MR) twice daily $(1.75 \mathrm{~L} /$ feeding from d 1 to $\mathrm{d}$ 10 of life, and $2.6 \mathrm{~L} /$ feeding from d 11 to d 15 of life at a concentration of $140 \mathrm{~g} / \mathrm{L}$ ). One week before enrolling the calves to the study, a pulmonary ultrasound (Easi Scan Linear, BCF Technology Ltd.) was performed to exclude calves with pulmonary lesions. Finally, 20 crossbred Angus-Holstein bull calves $(44.1 \pm 2.04 \mathrm{~kg}$ BW and $14.7 \pm 0.63 \mathrm{~d}$ of age) were transported $1 \mathrm{~h}$ from their origin dairy farm to a commercial beef farm located in Lleida, Spain (Agropecuària Montgai S.L). At arrival, calves were weighed, received an intranasal vaccine against respiratory syncytial virus and parainfluenza 3 (Bovilis INtranasal RSP Live, MSD Animal Health), and were distributed in individual hutches. Commonly, unweaned calves are collected from their origin farms and transported to an assembly center before a short or long transport to rearing facilities. At the assembly centers, calves may be fed milk replacer or rehydrating solutions for a period of 1 to $3 \mathrm{~d}$. Regulations from the European Commission require a maximum of $9 \mathrm{~h}$ of transportation for unweaned calves (short transport) or 2 trips of $9 \mathrm{~h}$ with a 1-h rest stop in between when longer distances are needed (long transport; European Council, 2005). For this experiment, to simulate calves staying at an assembly center, different feed restriction levels were applied, and to simulate calf transport, different fasting duration times were combined with feed restriction levels, resulting in the following 4 randomly assigned treatment groups. Control treatment (CT; n $=5$ ): calves were fed $2.5 \mathrm{~L}$ of $\mathrm{MR}$ at a concentration of $140 \mathrm{~g} / \mathrm{L}$ as fed twice daily; water, concentrate (Table 1 ), and straw were offered ad libitum. These animals were not subjected to feed restriction or any type of fasting. Mild treatment (MD; $\mathrm{n}=5)$ : calves were fed $2.5 \mathrm{~L}$ of $\mathrm{MR}$ at a concentration of $140 \mathrm{~g} / \mathrm{L}$ as fed twice daily from $\mathrm{d}-4$ to $\mathrm{d}-1$ and had ad libitum access to water; at the end of $\mathrm{d}-1$, these animals were fasted for $9 \mathrm{~h}$. Moderate treatment (MO; $\mathrm{n}=5)$ : calves were fed $2.5 \mathrm{~L}$ of $\mathrm{MR}$ at a concentration of $140 \mathrm{~g} / \mathrm{L}$ as fed twice daily from $\mathrm{d}-4$ to $\mathrm{d}-1$, with ad libitum access to water; at the end of $d-1$, these animals were fasted for $19 \mathrm{~h}$. Severe treatment $(\mathbf{S V} ; \mathrm{n}=5)$ : calves were fed $2.5 \mathrm{~L}$ of a rehydration solution $(\mathbf{R S})$ at a concentration of $50 \mathrm{~g} / \mathrm{L}$ as fed twice daily from $\mathrm{d}-4$ to $\mathrm{d}-1$, with ad libitum access to water; at the end of $d-1$, these 
animals were fasted for $19 \mathrm{~h}$. The feeding schedule for $\mathrm{MR}$ was $0800 \mathrm{~h}$ for the morning feeding and $1700 \mathrm{~h}$ for the afternoon feeding. Milk refusals were recorded if present. The fasting period in the MO and SV groups took place from $1600 \mathrm{~h}$ on $\mathrm{d}-1$ to $1100 \mathrm{~h}$ on $\mathrm{d} 0$, simulating a calf transport of $19 \mathrm{~h}$ (calves missed $2 \mathrm{MR}$ feedings and spent a total of $26 \mathrm{~h}$ fasting, considering the last MR feeding). For the MD treatment, the fasting period went from $0200 \mathrm{~h}$ until $1100 \mathrm{~h}$, simulating a 9-h transport (calves missed $1 \mathrm{MR}$ feeding and spent a total of $17 \mathrm{~h}$ fasting, considering the last MR feeding). During the fasting period, calves were not offered MR, concentrate, or water.

After application of treatments, from d 0 until weaning on d 42, all calves were fed equal amounts of MR and had ad libitum access to concentrate, straw, and water. This phase was intended to mimic the arrival of calves to a calf-rearing facility. During this period, calves were fed $2.5 \mathrm{~L}$ of $\mathrm{MR}$ at a concentration of 140 $\mathrm{g} / \mathrm{L}$ as fed twice daily (following the feeding protocol explained earlier) from d 0 to $\mathrm{d} 7$ of the study. From d 8 until d 24 calves were fed $2 \mathrm{~L}$ of MR at a concentration of $125 \mathrm{~g} / \mathrm{L}$ as fed twice daily. Finally, from d 25 until weaning on d 42 , calves were fed $2 \mathrm{~L}$ of MR at a concentration of $125 \mathrm{~g} / \mathrm{L}$ as fed once a day (a.m.). From d -4 to d 24, calves were fed the same MR offered at the origin dairy farm $(24.3 \% \mathrm{CP}, 20.7 \%$ fat; Serval S.A.S. $)$ to ensure that the potential dietary effect of MR could not be confounded with the treatment effect. Then, from d 25 until d 42, an MR containing 22.8\% CP and $18.7 \%$ ether extract (Karizoo S.A.) was used. Milk replacer was prepared on milk taxis (H\&L Milk Taxi, Holm \& Laue). At each milk feeding time, milk concentration $(\mathrm{g} / \mathrm{L})$ and temperature $\left(60^{\circ} \mathrm{C}\right.$ at manufacture, and between 40 and $45^{\circ} \mathrm{C}$ at feeding) were recorded using a clinical refractometer and a thermometer, respectively. The RS used in the SV group contained $84.5 \%$ glucose monohydrate, $11.0 \%$ salt, $4.5 \%$ monopotassium phosphate, $76.0 \%$ glucose, $14.5 \%$ ashes, $1.0 \%$ phosphorus, $4.1 \%$ sodium, $10.4 \%$ chloride, $1.3 \%$ potassium, and 2.8 Mcal of ME $/ \mathrm{kg}$, DM basis (Corion, DLB Laboratories). From $\mathrm{d}-4$ for $\mathrm{CT}$, and $\mathrm{d} 0$ for MD, MO, and SV, until d 11 of the study, calves were fed a commercial texturized concentrate, and from d 12 until weaning, concentrate pellets were used (Table 1). Transition between the 2 concentrates was performed by mixing them at a 50/50 concentration for $6 \mathrm{~d}$ (from d 12 to d 17) to avoid a reduction in concentrate intake. From $\mathrm{d}-4$ for $\mathrm{CT}$, and $\mathrm{d} 0$ for $\mathrm{MD}, \mathrm{MO}$, and $\mathrm{SV}$, until weaning on $\mathrm{d}$ 42 , chopped barley straw was offered. Both concentrate and straw were offered ad libitum. Water was offered ad libitum from $\mathrm{d}-4$ for all treatments, except during the fasting period for MD, MO, and SV calves simulating transportation.
Table 1. Ingredient composition and nutrients of the concentrates used in the study

\begin{tabular}{lcc}
\hline & \multicolumn{2}{c}{ Concentrate } \\
\cline { 2 - 3 } & Texturized & Pellet \\
Item & $(\mathrm{d}-4$ to d 11$)$ & $(\mathrm{d} 12$ to d 42$)$ \\
\hline Ingredient composition, $\%$ & 28.3 & \\
Soybean meal & 21.2 & - \\
Cornflake & 20.7 & - \\
Wheat bran & 12.2 & - \\
Beet pulp & 5.8 & - \\
Beet molasses & 5.2 & - \\
Whey powder & 4 & 1.74 \\
Extruded soybean & 0.54 & 0.4 \\
Calcium carbonate & 0.21 & 0.4 \\
Dicalcium phosphate & 0.11 & 33 \\
Sodium chloride & - & 30.5 \\
Corn & - & 8 \\
Barley & - & 9 \\
Wheat middling & 1.74 & 15.63 \\
Premix & & 4.72 \\
Nutrient, \% DM & 19.1 & 13.45 \\
CP & 5.4 & 7.05 \\
EE & 19.5 & 4.44 \\
NDF & 9.6 & 44.26 \\
ADF & 5.3 & \\
Ash & 26 & \\
Starch & & \\
\hline
\end{tabular}

${ }^{1} \mathrm{EE}=$ ether extract.

\section{Measurements and Sample Collection}

Body weight was recorded at arrival on $\mathrm{d}-4$, on $\mathrm{d}-1,0,2,7,14,21,28,35$, and at weaning on $\mathrm{d}$ 42 of the study. Concentrate feed offered and refused were daily recorded for further concentrate feed intake calculations. Daily water intake was also recorded. Straw was provided to stimulate rumen growth; however, measurements were difficult to perform because hutches were exposed to environmental conditions that interfered with its recording.

On d $-4,-1,0,2,14,21$, and 42 , blood samples were collected. Samples were collected before the morning feeding from the jugular vein, using evacuated serum tubes (BD Vacutainer Plus Plastic Serum Tubes). Serum was used for measurements of energy balance markers [nonesterified fatty acids (NEFA) and BHB), and gut integrity (citrulline). An additional blood sample was collected with BD Vacutainer Fluoride Tubes for plasma glucose concentration analyses. Blood was centrifuged at $1,500 \times g$ at $4^{\circ} \mathrm{C}$ for $15 \mathrm{~min}$, and serum and plasma were obtained and stored at $-20^{\circ} \mathrm{C}$ until further analysis.

A permeability test was conducted on $\mathrm{d}-4,-1,0$, and 2 of the study. For this test, lactulose, D-mannitol, and chromium $(\mathrm{Cr})$-EDTA were used as markers of intestinal permeability. The concentrations of these markers were based on a previous study (Amado et 
al., 2019). For this test, lactulose $(0.4 \mathrm{~g} / \mathrm{kg}$ of $\mathrm{BW}$; Duphalac), D-mannitol (0.12 g/kg of BW; SigmaAldrich Corp.), and Cr-EDTA (0.1 g/kg of BW; SigmaAldrich Corp.) were dissolved separately in $100 \mathrm{~mL}$ of warm water (Amado et al., 2019). Markers were given to the calves $2 \mathrm{~h}$ after the morning feeding on $\mathrm{d}-1$ and 2 , and before the morning feeding on $\mathrm{d}-4$ (at arrival to the rearing facility) and 0 (after the fasting period), using 100-mL syringes. Each marker was charged in separated syringes and administered directly into the oral cavity of each calf. Blood samples were collected 120 min after markers' administration. To decide the optimum sampling time for markers of intestinal permeability, blood samples were collected at $60,120,180$, and 240 min after administration of the markers. Major differences in the area under the curve of markers between $\mathrm{CT}$ and the restricted treatments were observed at $120 \mathrm{~min}$ (data not shown). Measurements of these markers are normally expensive and time consuming; for that reason, optimization of the technique and the number of samples to be processed is required. Samples were obtained from the jugular vein and collected in evacuated serum tubes (BD Vacutainer Plus Plastic Serum Tubes). After collection, samples were stored at room temperature for $1 \mathrm{~h}$ to allow the blood to clot and then centrifuged at $1,500 \times g$ at $4^{\circ} \mathrm{C}$ for $15 \mathrm{~min}$. The obtained serum was aliquoted in 1-mL microcentrifuge tubes and stored at $-20^{\circ} \mathrm{C}$ until further analysis.

From d -4 to 7 , accelerometer data loggers (Hobo Pendant G Data Logger, Onset Computer Corporation) were placed between the hock and the fetlock of the right hind limb of each calf for measurements of standing time, standing duration, and standing bouts. The accelerometers were covered with a foam pad to protect the calves from abrasions and attached with self-adhesive elastic bandages. Standing behavior was recorded at 1-min intervals. Data from the data loggers were recovered using HOBOware software version 3.7.23 (Onset Computer Corporation).

\section{Chemical Analysis}

Feed samples from both concentrates used in the study were collected and analyzed for DM $(24 \mathrm{~h}$ at $\left.103^{\circ} \mathrm{C}\right)$, ash $\left(4 \mathrm{~h}\right.$ at $\left.550^{\circ} \mathrm{C}\right)$, CP by the Kjeldahl method (method 981.10; AOAC International, 1995), and ADF and NDF (method 973.18; AOAC International, 1996). Milk replacer samples were collected and analyzed for $\mathrm{DM}\left(24 \mathrm{~h}\right.$ at $\left.103^{\circ} \mathrm{C}\right)$, ash $\left(4 \mathrm{~h}\right.$ at $\left.550^{\circ} \mathrm{C}\right), \mathrm{CP}$ by the Kjeldahl method (method 981.10; AOAC International, 1995), and sugars (HPLC-Refractive Index; method 984.22; AOAC International, 2002).

Serum glucose concentration was determined following the hexokinase method (OSR 6121, Beckman Coul- ter Inc.) The intra-assay coefficient of variation was $<0.70 \%$. Serum NEFA concentration was determined by the enzymatic colorimetric method with NEFA-C reagent (Wako Chemicals $\mathrm{GmbH}$ ). The intra- and interassay coefficients of variation were $4.46 \%$ and $1.62 \%$, respectively. Serum BHB was determined using a kinetic enzymatic method (Randox Laboratories Ltd.) The intra- and interassay coefficients of variation were $2.69 \%$ and $0.44 \%$, respectively. Serum citrulline concentration was measured using a spectrophotometric kit (L-Citrulline Kit, Immundiagnostik AG) The intraand interassay coefficients of variation were $9.75 \%$ and $5.12 \%$, respectively. Analysis of lactulose and D-mannitol in serum extracts was performed in an Acquity UPLC (Waters Corp.) connected to a Xevo-G2 QTof mass spectrometer (Waters Corp.) operating in a negative mode (100 to $1,200 \mathrm{~m} / z)$. Serum extracts $(2 \mu \mathrm{L})$ were injected into an ethylene bridged hybrid (BEH) amide column $(2.1 \mathrm{~mm} \times 100 \mathrm{~mm}, 1.7 \mu \mathrm{m}$, Waters Corp.) and analytes eluted using mobile phases comprising $\mathrm{A}=10 \mathrm{~m} M$ ammonium acetate in acetonitrile: water $\left(\mathrm{ACN}: \mathrm{H}_{2} \mathrm{O}\right)$ at a ratio of $9: 1$ and $\mathrm{B}=10 \mathrm{~m} M$ ammonium acetate in $\mathrm{ACN}: \mathrm{H}_{2} \mathrm{O}$ (4:6). Flow rate was set to $0.5 \mathrm{~mL} / \mathrm{min}$, and column and auto-sampler chamber temperatures were maintained at 40 and $10^{\circ} \mathrm{C}$, respectively. Leucine-enkephalin $(200 \mathrm{ng} / \mathrm{mL})$ was used as lock mass for mass accuracy and infused at a flow rate of $10 \mu \mathrm{L} / \mathrm{min}$. Serum samples were subjected to protein precipitation with $20 \mu \mathrm{L}$ of internal standard solution $+130 \mu \mathrm{L}$ of ACN: $\mathrm{H}_{2} \mathrm{O}(8: 2)$ and analyzed in 4 independent replicates per sample. Chromatograms were processed using QuanLynx software (version 4.1, Waters Corp.). Ion areas were used for quantification based on standard curves prepared using authentic standards and raffinose as internal standards. Serum Cr-EDTA was determined by inductively coupled plasma-optical emission spectrometry, using an inductively coupled plasma mass spectrometer (ICP-MS, Agilent 7500ce). The intra- and interassay coefficients of variation were $<10 \%$ and $<15 \%$, respectively.

\section{Statistical Analysis}

A power analysis was conducted to determine the experimental units needed. The type I error rate $(\alpha)$ was 0.05 , and the power $(1-\beta)$ was set at $80 \%$. Concentration of Cr-EDTA, was considered our primary outcome. Based on the differences in Cr-EDTA in Amado et al. (2019) and the severity of the fasting treatments, assuming differences among treatments of $30 \%$ the minimum sample size was 5 . Calf was the experimental unit. The study design was a randomized complete balanced design with a covariance adjustment. The model included the random effect of pen and the fixed effect 
of treatment, time, and their interaction and initial BW as a covariate. Data were analyzed using the MIXED procedure of SAS (version 9.4, SAS Institute Inc.) with repeated measurements for those continuous variables with multiple sampling over time. The compound symmetry covariance structure, the first-order autoregressive covariance structure, and the unstructured covariance structure were tested according to the time points, and the Kenward-Roger degrees of freedom were used based on the lower Bayesian information criterion value. Initial BW and age were analyzed using the MIXED procedure with treatment as fixed effect. Differences were declared significant at $P \leq 0.05$, and trends were discussed at $0.05 \leq P \leq 0.10$ for all models.

\section{RESULTS AND DISCUSSION}

\section{Recovery: Body Weight, Feed Consumption, and Behavior}

During the feed restriction period (period when calves were fed nutrients below their nutritional requirements), simulating an assembly center (from d -4 to $\mathrm{d}-1$ ), feeding oral RS impaired calves' BW in contrast with MR-fed calves $(P<0.01$; Figure 1$)$. After the fasting period (period of complete absence of feed and water), simulating transport, from d 0 to $\mathrm{d} 7$ all restricted treatments (MD, MO, and SV) recovered their BW, although they did not achieve CT calves' BW ( $P$ $<0.01$; Figure 1). Within the restricted groups, MD calves had greater BW recovery compared with MO and SV. Differences in BW at d 7 (Figure 1) among $\mathrm{MD}, \mathrm{MO}$, and SV treatments could be related to the severity of the feed restriction (MR or RS) and the duration of fasting (9 vs. $19 \mathrm{~h}$ ). A time by treatment interaction was observed on energy intake $(P<0.01$; Table 2). Calves under the SV treatment received 1.34 $\pm 0.228 \mathrm{Mcal} / \mathrm{d}( \pm \mathrm{SE})$ during their feed-restrictive phase, whereas MD and MO consumed $3.36 \pm 0.228$ $\mathrm{Mcal} / \mathrm{d}$, and CT calves consumed $3.61 \pm 0.228 \mathrm{Mcal} / \mathrm{d}$. No differences were observed in protein intake (Table 2). In addition, minor $\mathrm{BW}$ gains were observed for $\mathrm{MO}$ and SV calves after the transport simulation (from d 2 to d 7) due to the longer hours of fasting (19 h), which probably caused shrinkage due to content loss (manure, urination; González et al., 2012) and dehydration (von Borell, 2001). These differences among treatments, although minor, remained until d 21 of the study (time by treatment interaction, $P=0.04$; Figure 2). Unexpectedly, at weaning on $\mathrm{d} 42$, MO calves had the lowest BW compared with the other treatments (Figure 2).

Monitoring BW changes in the first weeks of age provides relevant information, as the first week after arrival to the feedlot has been described as a critical period when calves' intake normally decreases (Hutcheson and Cole, 1986; Loerch and Fluharty, 1999). Marcato et al. (2018) observed that pre-transport diet and transport duration have a direct effect on these animals' performance in the first weeks after arrival to the rearing facility. In the present study, even though calves were subjected to different degrees of feed restriction and duration of fasting, the recovery in concentrate intake attenuated differences in BW by d 7 after application of treatments. Similarly, BW recovery after a few days following transportation and feed restriction has been previously reported in calves (Hutcheson and Cole, 1986; Marques et al., 2012). Bernardini et al. (2012) showed that losses in BW due to long-haul transportation $(19 \mathrm{~h})$ of male Holstein calves recovered by $\mathrm{d}$ 3 after transportation and access to feed and water. Similarly, previous research has shown that pre-transport BW was regained in transported calves between 8 and 16 h (Knowles et al., 1999) and 24 h (Knowles et al., 1997) after transportation. Altogether, results from these studies reinforce the idea that a quick intake recovery can have an almost immediate effect on calves' BW. Likewise, but considering the age difference with the calves from our study, previous research evaluating continuous transportation versus transportation with 2-h rest stops in recently weaned Angus $\times$ Hereford steers showed that even though ADG was lesser for transported animals compared with the control (not transported ones), those differences were not sufficient to influence BW by d 28 after arrival to the feedlot (Cooke et al., 2013).

An interaction between time and treatment $(P=$ 0.04; Figure 3) in concentrate feed intake was observed. From $\mathrm{d}-4$ to $\mathrm{d}-1$, only CT calves were offered concentrate, and their average concentrate intake was 86 $\pm 0.1 \mathrm{~g} / \mathrm{d}$. Restricted calves (MD, MO, and SV) were not offered concentrate until d 0 of the study; however, at $\mathrm{d} 0$ they consumed concentrate amounts similar to that of CT calves. At d 1 in the restricted calves (MD, $\mathrm{MO}$, and SV) an important drop in concentrate was observed. Gradually, SV calves recovered their intake close to $\mathrm{CT}$ values, although this recovery was not observed in MO and MD calves. The sudden access to concentrate after a hunger period with a digestive tract (rumen and small intestine) unprepared for such great increases in consumption could have provoked subclinical ruminal acidosis (Kim et al., 2016), rumen acidosis (Pederzolli et al., 2018), or other digestive disturbances, causing the drop in consumption observed on $\mathrm{d} 1$. According to the behavior data on d 1 (Figure $4 \mathrm{~A}$ ), when calves recovered their intake and showed the drop on concentrate intake, all treatments decreased their 
standing duration with no differences among groups after recovery of milk and concentrate intake from $\mathrm{d}$ 2 until d 10. Regarding calf behavior, SV calves spent more time standing (time by treatment interaction, $P$ $<0.01$; Figure $4 \mathrm{~A}$ ), and had greater standing duration (time by treatment interaction, $P=0.02$; Figure $4 \mathrm{~B}$ ) and fewer standing bouts (time by treatment interaction, $P<0.01$; Figure $4 \mathrm{C}$ ) from d -3 until d 0 (end of the restriction and fasting period) compared with the others during the restriction and fasting period. This behavior denoted the stress derived from hunger. Stress could have potentially generated a higher fat mobilization as expressed by the increment on serum NEFA concentration on $\mathrm{d}-1$ and $\mathrm{d} 0$ (Figure $5 \mathrm{~B}$ ). Mobilized fat used as a source of energy could explained the major BW losses in SV calves. Back to concentrate intake, by d $6 \mathrm{SV}$ calves showed the greatest concentrate increment, reaching values close to those of the CT group. Although the fasting hours between $\mathrm{MO}$ and SV calves were the same, concentrate intake recovery was lesser for MO calves. This could be explained as a process of compensatory growth after a period of feed restriction (Alves Costa et al., 2019). Compensatory growth has been widely studied in cattle as a physiological process where animals increase their muscle protein synthesis after a period of restricted development, usually due to a reduction in feed intake (Therkildsen, 2005). Additionally, it has been demonstrated that the level of feed restriction is proportional to the magnitude of the compensation (Coleman and Evans, 1986). The SV calves were exposed to a higher degree of feed restriction because of their diet based on a rehydrating solution, and because of that they might have experienced a higher degree of compensatory growth compared with the MO calves. Accordingly, Hutcheson and Cole (1986) demonstrated that calves arriving to the feedlot after a period of marketing and transportation consume only 0.5 to $1.5 \%$ of their BW during the first week, recovering normal intake between the second and fourth week after arrival to the feedlot. In agreement, in the present study calves consumed $0.7,0.4,0.4$, and $0.5 \%$ of their $\mathrm{BW}$ for $\mathrm{CT}, \mathrm{MD}, \mathrm{MO}$, and $\mathrm{SV}$, respectively from $\mathrm{d} 1$ to d 7 of the study. At weaning on d 42, concentrate feed intake did not show any significant differences among treatments $(P=0.39)$.

Finally, water consumption was similar among treatments from d 0 until d $42(P=0.62$; Table 2). Even though results from intake and $\mathrm{BW}$ were equal by the

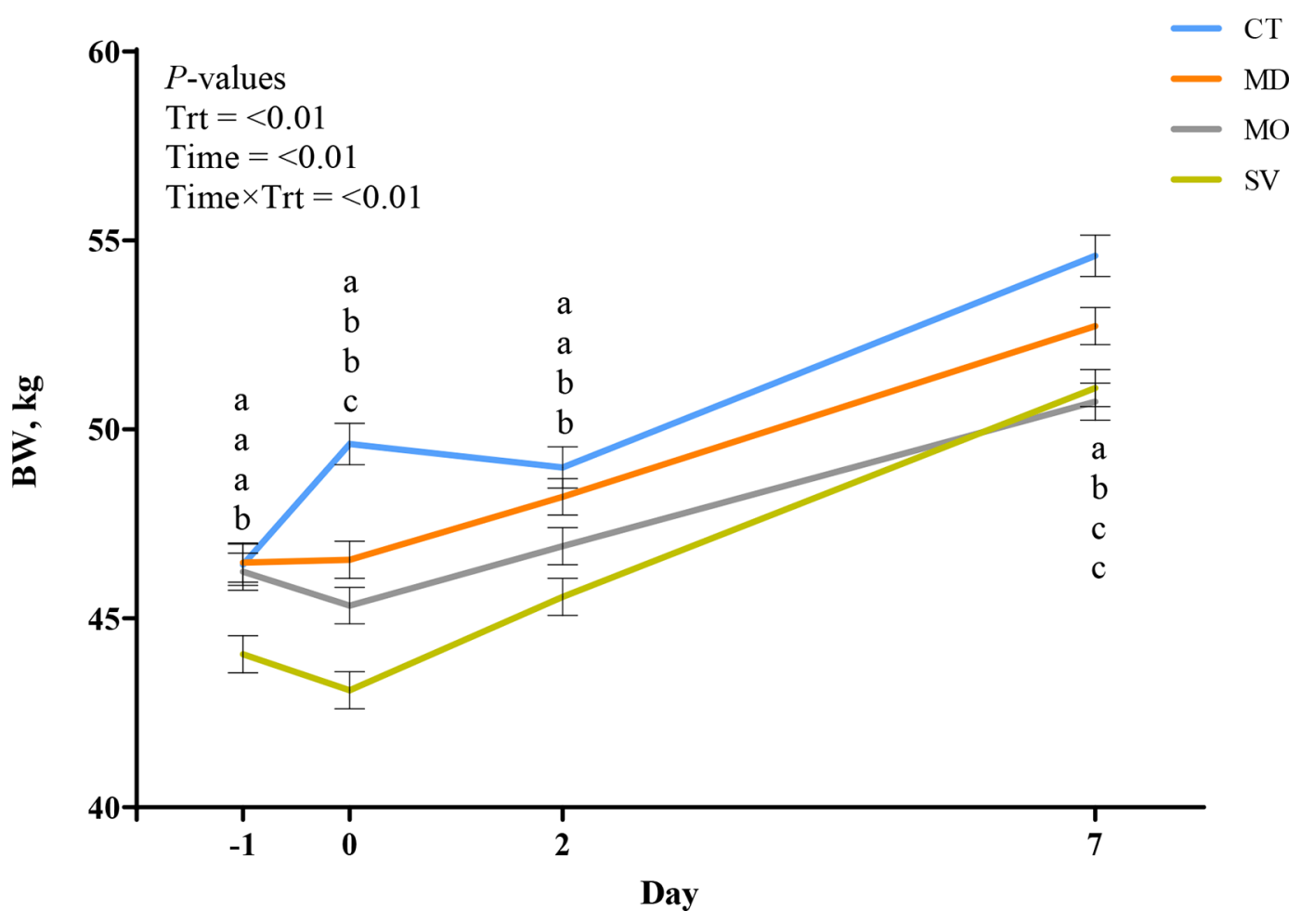

Figure 1. Evolution of BW recovery (mean $\pm \mathrm{SE}$ ) in crossbred Angus-Holstein bull calves fed milk replacer (MR) and not subjected to feed restriction or fasting (control, CT), fed MR and fasted for $9 \mathrm{~h}$ (mild restriction, MD), fed MR and fasted for $19 \mathrm{~h}$ (moderate restriction, MO), or fed a rehydration solution and fasted for $19 \mathrm{~h}$ (severe restriction, SV) from d -1 (end of the feed restriction and fasting period) to d 7 . The BW from d -4 was used as a covariate. Different letters within a time point denote differences among treatments $(P<0.05)$; order of the letters denotes the treatment with the highest value. Trt = treatment. 
Table 2. Initial age, BW, ADG, and intake of crossbred Angus-Holstein bull calves fed milk replacer (MR) and not subjected to feed restriction or fasting (control, CT), fed MR and fasted for $9 \mathrm{~h}$ (mild restriction, MD), fed MR and fasted for $19 \mathrm{~h}$ (moderate restriction, MO), or fed a rehydration solution and fasted for $19 \mathrm{~h}$ (severe restriction, SV) from d -4 to $\mathrm{d}-1$ (feed restriction and fasting period) and from d 0 to $\mathrm{d} 42$ (weaning)

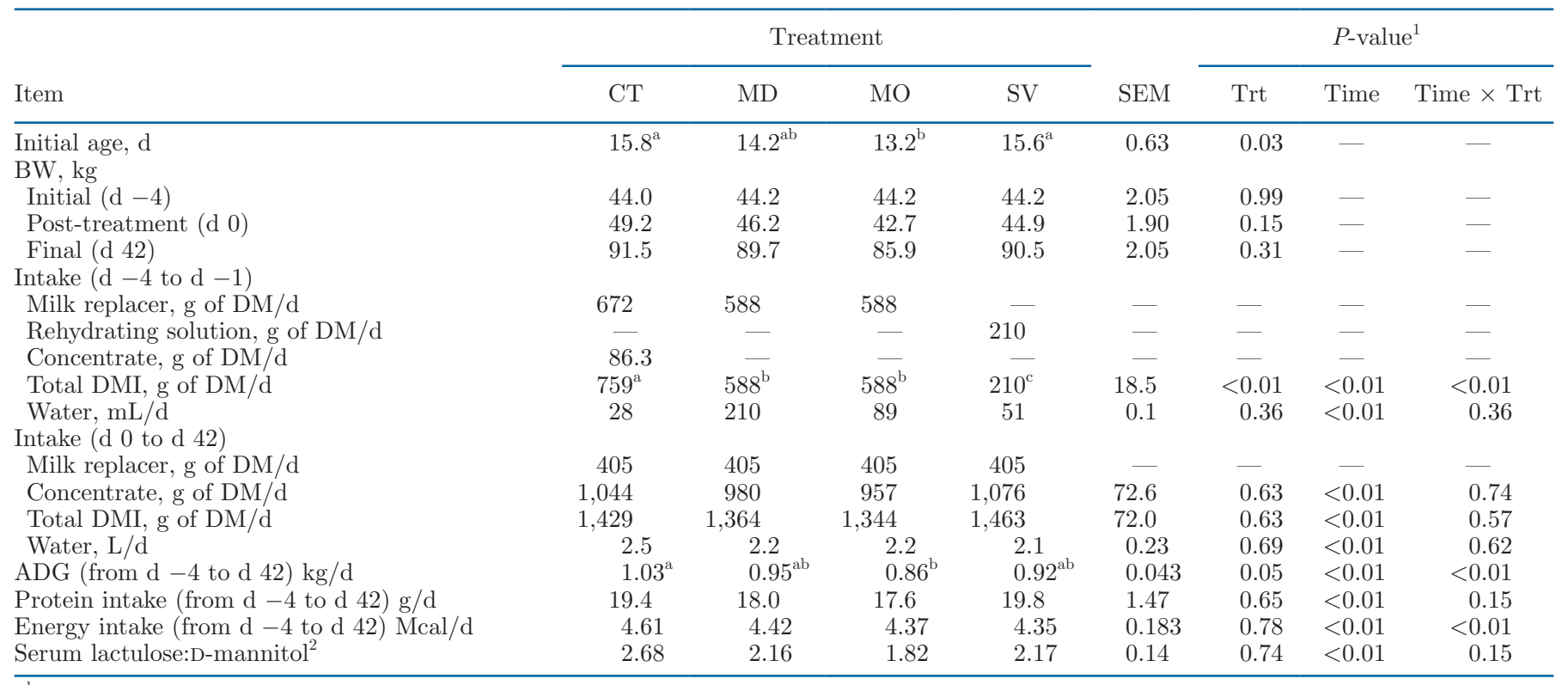

${ }_{\mathrm{a}, \mathrm{b}}$ Values with different superscripts within a row differ $(P \leq 0.05)$.

${ }^{1}$ Trt $=$ effect of feed restriction and fasting; Time $\times$ Trt $=$ effect of the time by treatment interaction.

${ }^{2}$ The values presented herein correspond to nontransformed means; however, SEM and $P$-values correspond to ANOVA using log-transformed data.

time of weaning for all treatments, the potential longterm effects that feed restriction might have on the overall performance and health status of these animals remains unclear, and further research should be conducted on this topic.

\section{Energy Balance}

Serum concentrations of glucose, NEFA, and BHB can be used as indicators of energy metabolism in calves. The hypothalamic-pituitary-adrenal axis and the consequent release of glucocorticoids and catecholamine during stressful conditions such as marketing and transportation generate changes in plasma glucose concentration (Herman et al., 2016). In the present study, serum concentration of glucose was lower at d -1 immediately after the feed restriction period (time by treatment interaction, $P<0.01$; Figure $5 \mathrm{~A}$ ) for the $\mathrm{SV}$ calves compared with the rest, whereas $\mathrm{MD}, \mathrm{MO}$, and $\mathrm{CT}$ showed similar concentrations. These results were expected, due to the energy deficit in the SV calves' diet based on a rehydrating solution with sugar as a source of energy, compared with the MR offered to the other restricted groups. By d 0, CT calves showed the highest $(P<0.01)$ concentration of glucose, whereas the restricted groups showed lower values. From the restricted groups, MD calves, which were fasted for $9 \mathrm{~h}$, had higher glucose concentration $(P=0.01)$ compared with MO and SV calves, which were fasted for $19 \mathrm{~h}$. These differences between the restricted groups show that the drop in glucose concentration during fasting is lower in those calves fasted for fewer hours (9 vs. $19 \mathrm{~h}$ ). After d 2, when calves recovered their intake, serum concentrations of glucose in feed-restricted calves reached concentrations similar to those of the CT group, and no differences among treatments were observed until weaning. Similar to our results, previous studies have shown a decrease in plasma glucose concentration during transportation that increased immediately following feeding in young calves (Mormede et al., 1982; Fröhli and Blum, 1988), Friesian-cross steers transported for $16 \mathrm{~h}$ with $12 \mathrm{~h}$ of lairage (Tadich et al., 2005), and 2-wk-old calves transported for $19 \mathrm{~h}$ with a 1-h rest stop (Knowles et al., 1999). Marcato et al. (2020) studied the effects of pre-transport diet (MR vs. RS), transport duration (6 vs. $18 \mathrm{~h}$ ), and transport conditions (open vs. air conditioned trucks) in physiological parameters of 368 unweaned male calves. Their study showed that calves fed either MR or RS and transported for $18 \mathrm{~h}$ had similar glucose concentrations; however, when transported for $6 \mathrm{~h}$, calves that were fed MR had higher glucose concentration compared with 


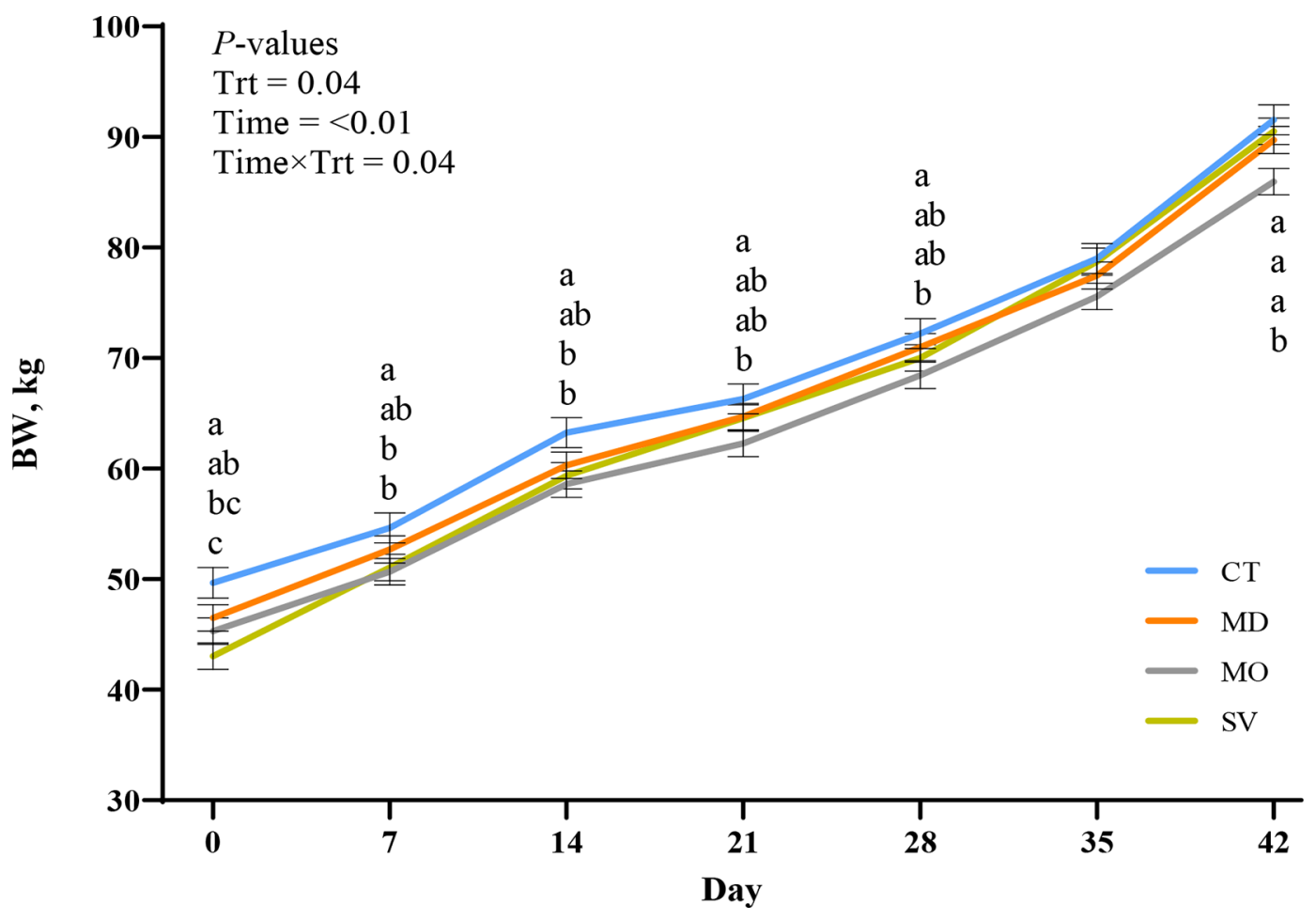

Figure 2. Evolution of BW recovery (mean $\pm \mathrm{SE}$ ) in crossbred Angus-Holstein bull calves fed milk replacer (MR) and not subjected to feed restriction or fasting (control, CT), fed MR and fasted for $9 \mathrm{~h}$ (mild restriction, MD), fed MR and fasted for $19 \mathrm{~h}$ (moderate restriction, MO), or fed a rehydration solution and fasted for $19 \mathrm{~h}$ (severe restriction, SV) from d 0 to d 42 . The BW from d -4 was used as a covariate. Different letters within a time point denote differences among treatments $(P<0.05)$; order of the letters denotes the treatment with the highest value. Trt $=$ treatment.

those fed RS (Marcato et al., 2020). In addition, calves fed MR and transported for $6 \mathrm{~h}$ had higher glucose and lower NEFA concentrations compared with calves fed MR but transported for $18 \mathrm{~h}$ (Marcato et al., 2020). This evidence could suggest that transportation length might influence calves' health status at arrival to the rearing facilities to a higher degree than pre-transport diet itself. Low plasma glucose concentrations have been associated with a higher mortality risk in calves after the first days following transportation (Mormede et al., 1982; Trunkfield and Broom, 1990; Renaud et al., 2018), although none of the calves in the present study died after the feed restriction and fasting suffered during the simulation of an assembly center and transportation.

Serum concentrations of NEFA and BHB showed differences among treatments throughout the study (time by treatment interaction, $P<0.01$; Figure 5 $\mathrm{B}$, and Figure $5 \mathrm{C}$, respectively). Both serum NEFA and $\mathrm{BHB}$ concentrations were greater in $\mathrm{SV}$ calves at $\mathrm{d}-1$ and 0 compared with the other treatments, and $\mathrm{MD}, \mathrm{MO}$, and CT showed similar concentrations. The greater concentrations of NEFA and BHB for the SV group might indicate that those calves mobilized body fat reserves, as observed by the lower BW described previously, causing a negative energy balance because these animals were offered only RS instead of MR during the restriction period. Even though adipose reserves in unweaned calves are limited, calves use lipids as an energy source to cope with negative energy balance conditions (Grigor et al., 2001; Bernardini et al., 2012). This switch to lipid oxidation is represented by the increment in plasma NEFA and BHB concentrations during feed withdrawal, especially noticeable for the most restricted group (SV). Serum concentrations of NEFA and BHB did not differ between $\mathrm{d}-1$ and $\mathrm{d} 0$ (fasting period) for $\mathrm{CT}, \mathrm{MD}$, and $\mathrm{MO}$ treatments. The lack of differences between MD and MO could indicate that $9 \mathrm{~h}$ or $19 \mathrm{~h}$ of fasting in MR-fed calves might not cause major effects on the energy balance. However, these differences could be masked due to the larger differences respective to the SV treatment. From d 2 until weaning, serum NEFA concentrations were similar for all treatments with the exception of the CT calves, which showed an unexpected increase at d 14 but equaled the others by d 42 . In accordance, Marti et al. (2017) found no differences in NEFA concentrations $2 \mathrm{~d}$ after 20 -h transportation in newly weaned beef calves. 
In all treatments, serum BHB concentration continued increasing after $\mathrm{d} 2$, reaching the greatest concentration at weaning. Increments in $\mathrm{BHB}$ concentrations near weaning are related to ruminal function development in calves, triggered by an increment in dry feed intake (Quigley et al., 1991).

\section{Intestinal Permeability}

Fasting and malnutrition have been related to a reduction in the number of intestinal cells, villus height, and increments in cell apoptosis (Ferraris and Carey, 2000; Moeser et al., 2012). In the present study different markers (serum citrulline, Cr-EDTA, lactulose, and D-mannitol) were used to evaluate gastrointestinal permeability after a feed restriction and fasting period. Serum citrulline concentration after the feed restriction period ( $\mathrm{d}-4$ to $\mathrm{d}-1$ ) was lesser in SV calves, followed by $\mathrm{MO}$ and $\mathrm{MD}$, and greatest in $\mathrm{CT}$ (time by treatment interaction, $P<0.01$; Figure 6 A). Surprisingly, at $\mathrm{d} 0$ even though $\mathrm{MD}, \mathrm{MO}$, and $\mathrm{SV}$ treatments went through a fasting period (9 or $19 \mathrm{~h}$ ), no differences among treatments in serum citrulline concentration were observed. However, and as a consequence of an increment in concentrate intake at $\mathrm{d} 1$, a serum citrulline concentration increment was observed by $\mathrm{d} 2$ for the CT calves. At d 14, an unexpected reduction of citrulline concentration was seen for the CT calves, probably associated with the unexpected increment in serum NEFA concentration in the same day for this group. However, by weaning on d 42 , no differences were found among treatments. Citrulline is a nonessential amino acid produced in the enterocytes of the small bowel (Windmueller and Spaeth, 1981), which has recently been studied as a potential biomarker of enterocyte mass and intestinal absorptive function (Gultekin et al., 2019) and as a negative inflammatory marker during acute or chronic intestinal insufficiency (Fragkos and Forbes, 2018). From the present results, it can be assumed that feed restriction might have affected the intestinal epithelium of the restricted calves to a certain extent, reflected by the lower levels of citrulline among those animals compared with the CT calves. Levels of citrulline incremented for all groups after the restriction period, probably due to reestablishment of normal function of the intestinal epithelium after recovering their intake. In agreement with our results, Gultekin et al. (2019) showed that citrulline levels in plasma were lower in neonatal calves with acute diarrhea compared with healthy calves.

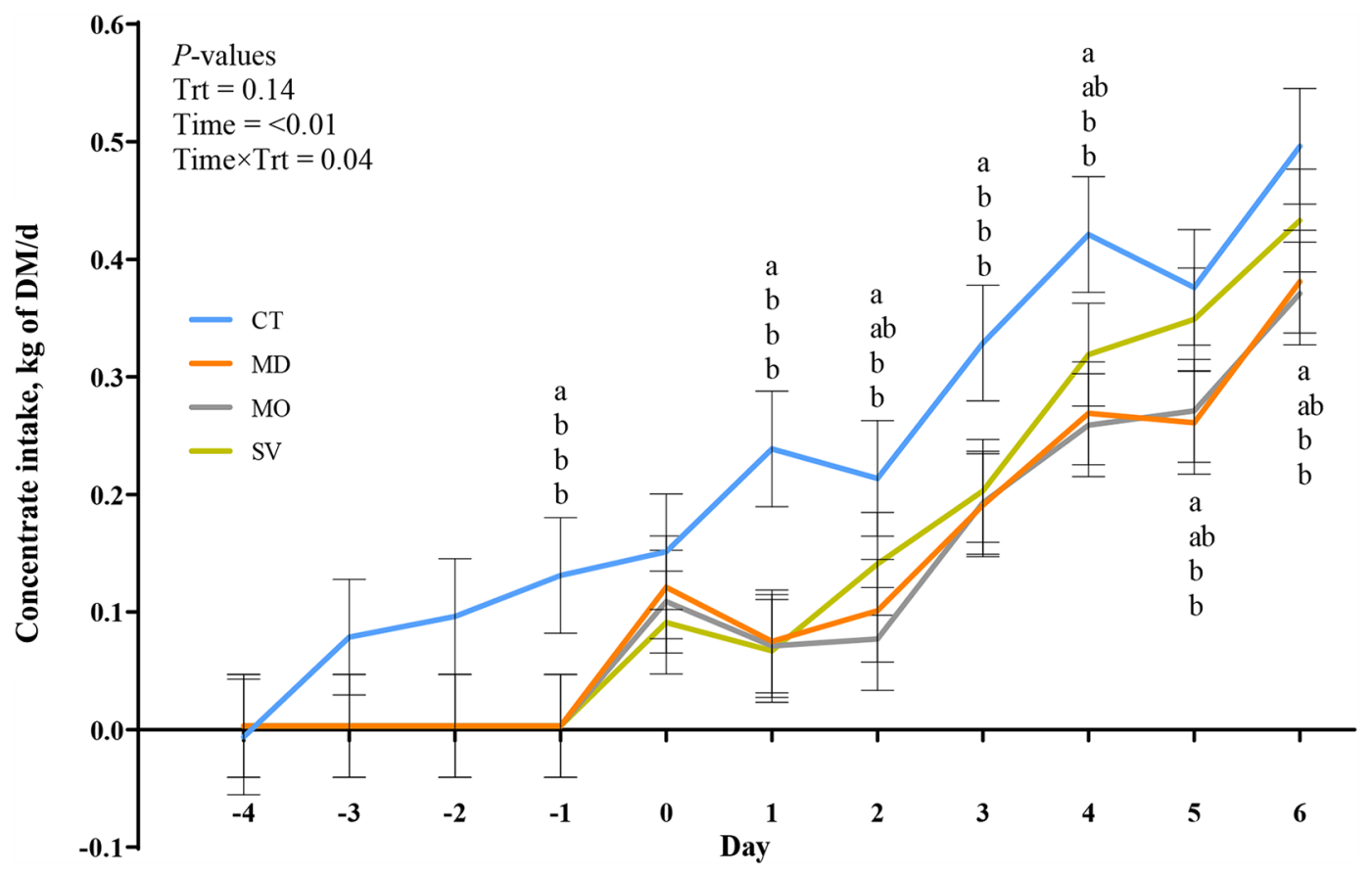

Figure 3. Evolution of concentrate intake (mean $\pm \mathrm{SE}$ ) in crossbred Angus-Holstein bull calves fed milk replacer (MR) and not subjected to feed restriction or fasting (control, CT), fed MR and fasted for $9 \mathrm{~h}$ (mild restriction, MD), fed MR and fasted for $19 \mathrm{~h}$ (moderate restriction, $\mathrm{MO}$ ), or fed a rehydration solution and fasted for $19 \mathrm{~h}$ (severe restriction, SV) from d -4 (start of the feed restriction period) to d 42 (weaning). Different letters within a time point denote differences among treatments $(P<0.05)$; order of the letters denotes the treatment with the highest value. Trt $=$ treatment. 
A

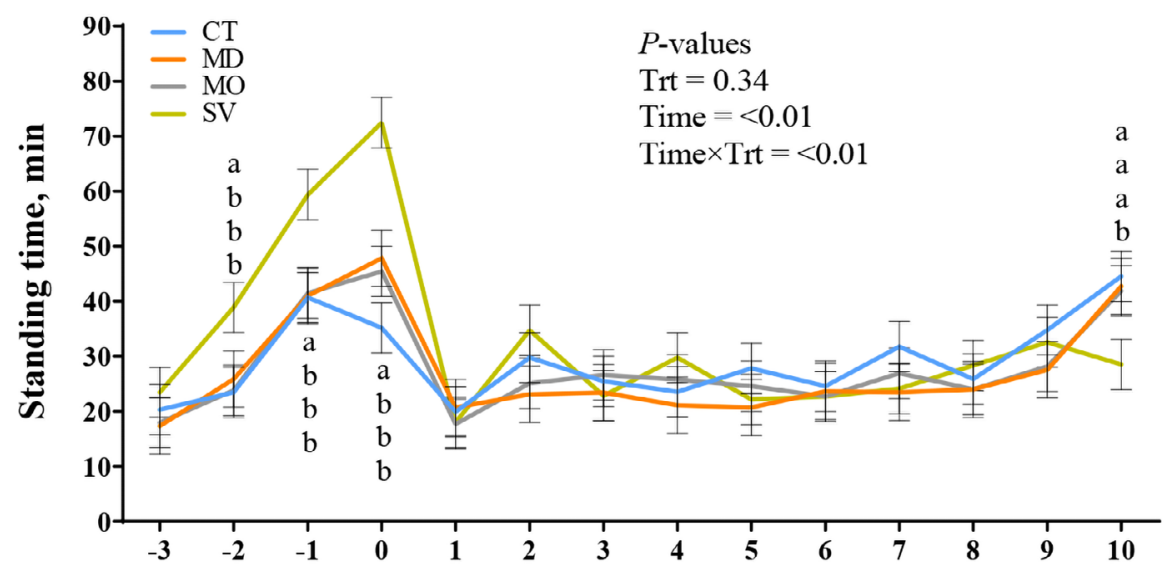

B
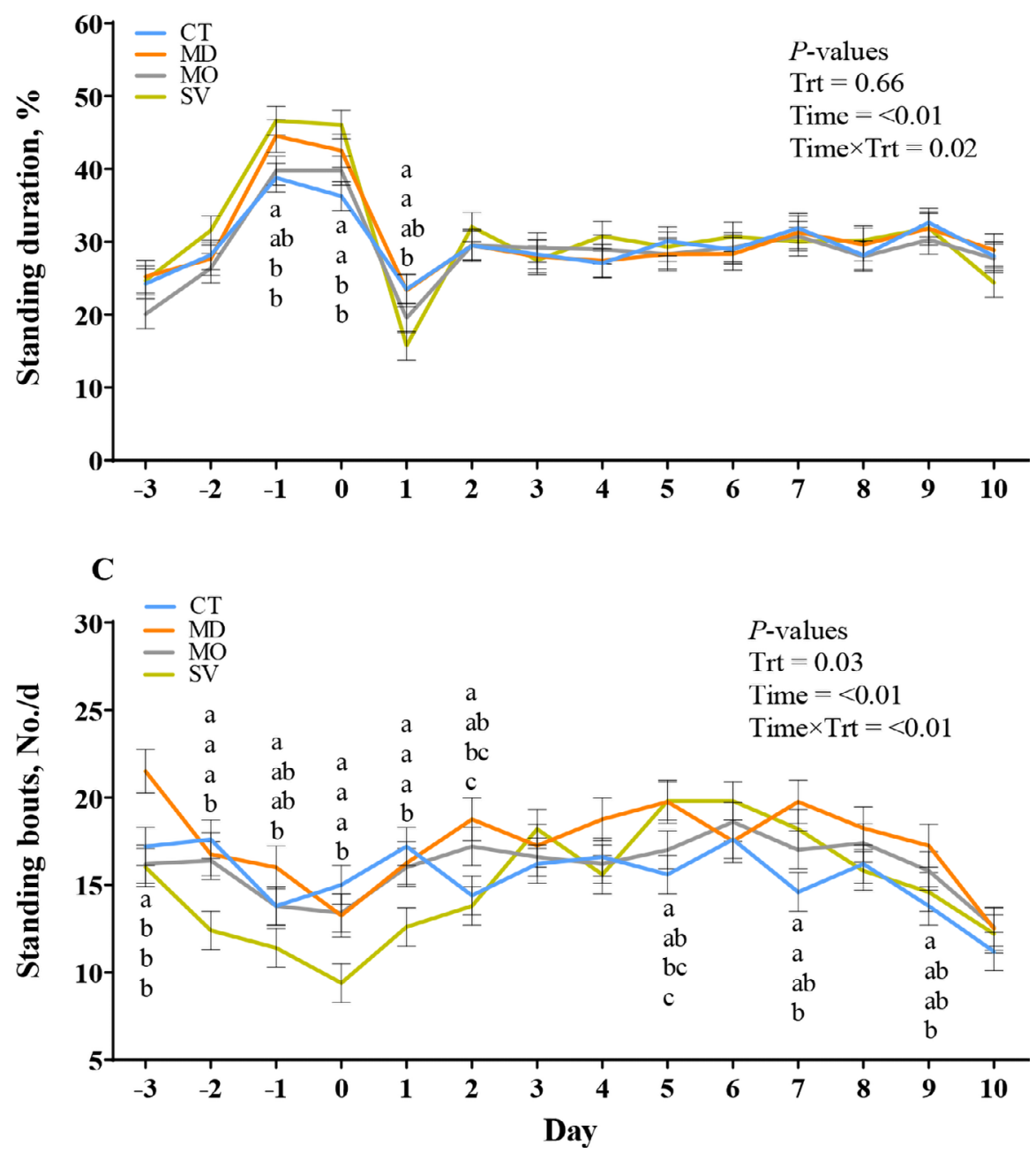

Figure 4. Pendant data loggers' records (mean $\pm \mathrm{SE}$ ) on standing time (A), standing duration (B), and number of standing bouts $(\mathrm{C})$ in crossbred Angus-Holstein bull calves fed milk replacer (MR) and not subjected to feed restriction or fasting (control, CT), fed MR and fasted for $9 \mathrm{~h}$ (mild restriction, MD), fed MR and fasted for $19 \mathrm{~h}$ (moderate restriction, MO), or fed a rehydration solution and fasted for $19 \mathrm{~h}$ (severe restriction, SV) from d -3 to d 10 of the study. Different letters within a time point denote differences among treatments $(P<0.05)$; order of the letters denotes the treatment with the highest value. Trt $=$ treatment. 

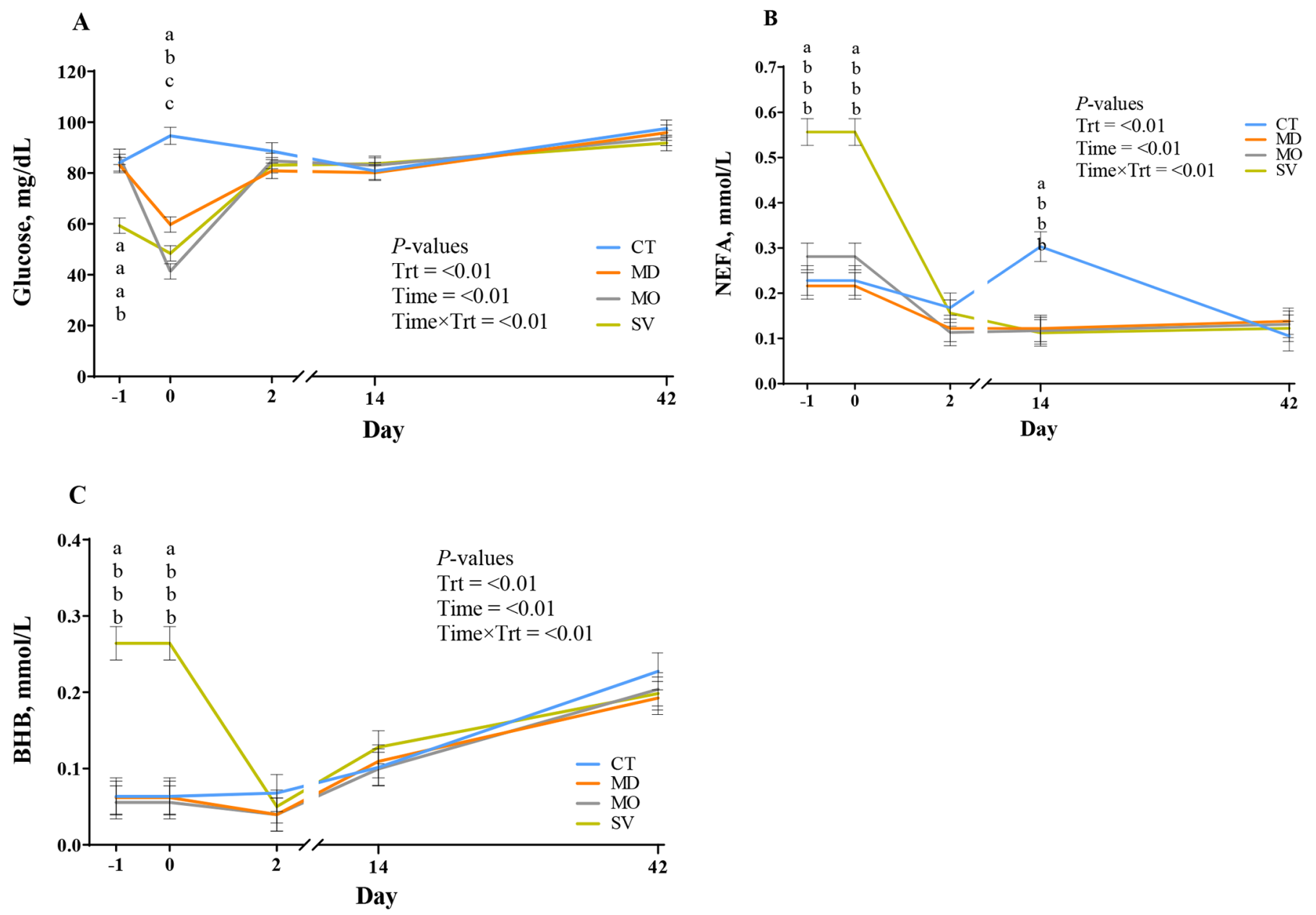

Figure 5. Serum concentrations (mean $\pm \mathrm{SE}$ ) of glucose (A), nonesterified fatty acids (NEFA, B), and BHB (C) in crossbred Angus-Holstein bull calves fed milk replacer (MR) and not subjected to feed restriction or fasting (control, CT), fed MR and fasted for 9 h (mild restriction, $\mathrm{MD}$ ), fed MR and fasted for $19 \mathrm{~h}$ (moderate restriction, MO), or fed a rehydration solution and fasted for $19 \mathrm{~h}$ (severe restriction, SV) from d -1 (end of the feed restriction and fasting period) to d 42 (weaning). Values from $\mathrm{d}-4$ were used as covariate. Different letters within a time point denote differences among treatments $(P<0.05)$; order of the letters denotes the treatment with the highest value. Trt $=$ treatment.

In relation to Cr-EDTA serum concentration, no time by treatment interaction was observed $(P=0.33$; Figure $6 \mathrm{~B}$ ). The CT calves showed the lowest serum concentration of Cr-EDTA, followed by MD and SV with intermediate concentrations, and MO calves presenting the highest concentration $(P<0.01)$. In calves Cr-EDTA has been widely used as a gastrointestinal permeability marker (Hunt et al., 2002; Wood et al., 2015; Wilms et al., 2019). It is an indigestible probe that can be measured in plasma, serum, and urine (Bischoff et al., 2014) after its passage through the paracellular space of adjacent enterocytes (Bjarnason et al., 1995), indicating an increment in the intestinal permeability to large molecules. Because Cr-EDTA is not fermented by bacteria in the gut (Aabakken, 1989), it is a trustable maker of total-tract barrier function
(Zhang et al., 2013). Previous studies have found increments of intestinal permeability in calves exposed to high-fat MR (Amado et al., 2019) and hypertonic MR (Wilms et al., 2019) using Cr-EDTA as a totaltract permeability marker. Results from the present study showed that CT calves had the lowest Cr-EDTA concentrations, whereas restricted calves showed the greatest concentration of this marker, demonstrating that the level of feed restriction can be positively associated with the recovery of Cr-EDTA in serum. It was expected that SV calves would have greater serum Cr-EDTA concentration than MO calves, as they suffered greater feed restriction. Despite this, our results are in accord with a previous study using Cr-EDTA as a marker of total-tract permeability conducted on heifers subjected to severe short-term feed restriction $(25 \%$ 
of voluntary intake for $5 \mathrm{~d}$ ), which showed a reduction in the intestinal barrier function of the total gastrointestinal tract (Zhang et al., 2013).

Finally, serum concentrations of lactulose and Dmannitol were also used as gastrointestinal permeability markers. Lactulose and D-mannitol have been extensively used for assessment of intestinal permeability in various species (Vilela et al., 2008; Araujo et al., 2015; Gilani et al., 2017). Lactulose is a disaccharide that, under physiological conditions, does not cross the intestinal layer and is normally fermented by bacteria in the colon (Schumann, 2002). When the integrity of the intestinal barrier is compromised, lactulose reaches the bloodstream via paracellular transport (Bischoff et al., 2014). On the other hand, D-mannitol, a monosaccharide, is normally absorbed in the small intestine via transcellular pathway (Arrieta et al., 2006). Recovery of lactulose and D-mannitol in blood or urine is com-
A
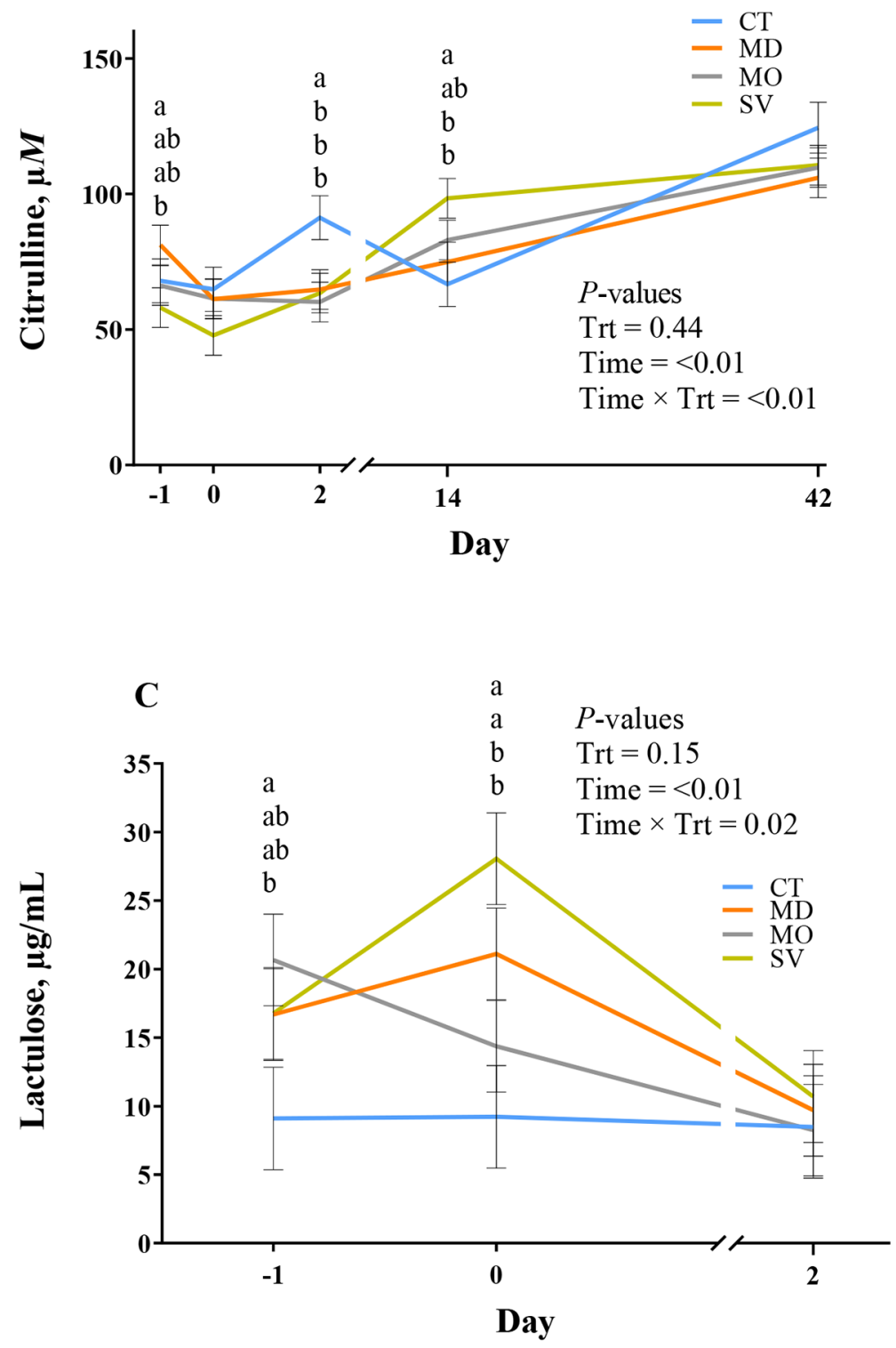

B

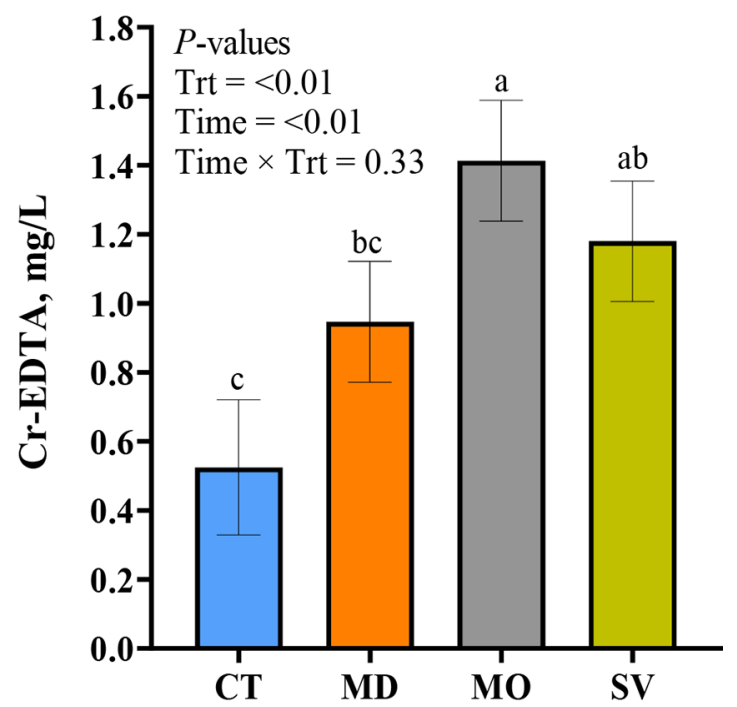

Figure 6. Serum concentrations (mean \pm SE) of citrulline (A), Cr-EDTA (B), and lactulose (C) in crossbred Angus-Holstein bull calves fed milk replacer (MR) and not subjected to feed restriction or fasting (control, CT), fed MR and fasted for $9 \mathrm{~h}$ (mild restriction, MD), fed MR and fasted for $19 \mathrm{~h}$ (moderate restriction, MO), or fed a rehydration solution and fasted for $19 \mathrm{~h}$ (severe restriction, SV) from d -1 (end of the feed restriction and fasting period) to d 42 (weaning) for citrulline and d 2 for Cr-EDTA, lactulose, and D-mannitol. Values from d -4 were used as covariate. Different letters within a time point denote differences among treatments $(P<0.05)$; order of the letters denotes the treatment with the highest value. Trt $=$ treatment 
monly used for assessment of intestinal integrity. In the present study at d 0, serum lactulose concentrations for $\mathrm{SV}$ and $\mathrm{MD}$ calves were greater compared with $\mathrm{CT}$ and $\mathrm{MO}(P=0.02$; Figure $6 \mathrm{C})$. A tendency $(P=$ 0.07 ) was observed for serum D-mannitol concentration. As observed with Cr-EDTA, serum concentration of Dmannitol tended to be lower for CT $(5.2 \pm 0.38 \mu \mathrm{g} /$ $\mathrm{mL})$ compared with $\mathrm{MO}(11.56 \pm 0.34 \mu \mathrm{g} / \mathrm{mL})$ and $\mathrm{SV}(10.08 \pm 0.34 \mu \mathrm{g} / \mathrm{mL})$, but no differences were seen between $\mathrm{CT}$ and $\mathrm{MD}(9.33 \mu \mathrm{g} / \mathrm{mL} \pm 0.34)$ and between MD and SV treatments. An increment in serum lactulose and D-mannitol concentration was expected for the restricted groups, assuming that feed restriction and fasting negatively affect the physiological functionality of the gastrointestinal tract. Our assumptions were partially confirmed when $\mathrm{CT}$ calves consistently showed the lowest concentrations of all biomarkers used in this study. However, the lack of differences in serum lactulose concentration between $\mathrm{CT}$ and $\mathrm{MO}$ calves on d 0 cannot be explained based on our assumptions. One possible explanation could be an effect based on sample size. Additionally, lactulose and D-mannitol could have suffered some level of fermentation in the reticulorumen due to the oral administration of these markers. At d 2 after the restriction period, no significant differences among treatments were found for serum concentration of lactulose. Kvidera et al. (2017) showed that progressive feed restriction in lactating cows increased intestinal permeability due to reductions in the mucosal surface area, ileum villus height, and goblet cell area. In addition, the stress suffered during feed restriction and the consequent increment in cortisol have been proposed as a potential mechanism of increased intestinal permeability (Kvidera et al., 2017; Horst et al., 2020). Results from the present study showed a clear effect of feed restriction and fasting on the gastrointestinal permeability of calves during a short-time restriction period. Results from Cr-EDTA and D-mannitol are close to those for serum citrulline. The lower serum citrulline concentration (low enterocyte mass) and high serum concentration of Cr-EDTA (increment of gastrointestinal permeability to large molecules) in the restricted groups compared with the CT group support the hypothesis that feed restriction has a negative effect on the normal physiological conditions of the intestinal barrier. However, further research needs to be done on the effects of feed restriction and fasting on morphological parameters of the gut wall. Additionally, there is a need for development of new techniques for assessment of intestinal and total-tract permeability, to make them less laborious and expensive to analyze. In this scenario, the analysis of citrulline concentration could be good method to assess gut permeability, as it does not require oral administration of markers and its determination can be easily performed via serologic assays.

\section{CONCLUSIONS}

The greater the degree of feed restriction and fasting before arrival at the rearing farm, the greater the negative effects on physiological parameters and markers of intestinal permeability. Additionally, a great degree of restriction together with a long fasting period alters animals' behavior, probably due to the stress caused by hunger. Most of the physiological and performance results were equal after recovery of feed intake among the restricted calves. By understanding how feed restriction affects performance, new feeding strategies could be implemented at assembly centers to enhance calves' health, gut function, and behavior.

\section{ACKNOWLEDGMENTS}

This research was funded by the DEMO "LEAKYGUT: Demostració de l'impacte que té l'alimentació prèvia a l'arribada a la granja sobre la salut i benestar dels vedells lactants," financially supported by Departament d'Agricultura, Ramaderia i Pesca (Generalitat de Catalunya, Barcelona, Spain) and the European Agricultural Fund for Rural Development (European Union, Brussels, Belgium). The Institut de Recerca i Tecnologies Agroalimentàries (Barcelona) also thanks the support of the Generalitat de Catalunya through the Centres de Recerca de Catalunya (Barcelona). Finally, the authors thank the collaboration of the personnel of the Granja San José (Lleida, Spain), Agropecuària Montgai S.L. (Lleida, Spain), and Carolina Tejero (MSD, Spain) for their assistance with calves' care and the collaboration of their personnel during the development of this study. The authors have not stated any conflicts of interest.

\section{REFERENCES}

Aabakken, L. 1989. Cr-ethylenediaminetetraacetic acid absorption test: Methodologic aspects. Scand. J. Gastroenterol. 24:351-358. https://doi.org/10.3109/00365528909093059.

Alves Costa, N., A. P. Pansani, C. H. de Castro, D. Basile Colugnati, C. H. Xaxier, K. C. Guimarães, L. Antas Rabelo, V. Nunes-Souza, L. F. Souza Caixeta, and R. Nassar Ferreira. 2019. Milk restriction or oligosaccharide supplementation in calves improves compensatory gain and digestive tract development without changing hormone levels. PLoS One 14:e0214626. https://doi.org/10.1371/ journal.pone.0214626.

Amado, L., H. Berends, L. N. Leal, J. Wilms, H. Van Laar, W. J. J. Gerrits, and J. Martín Tereso. 2019. Effect of energy source in calf milk replacer on performance, digestibility, and gut permeability 
in rearing calves. J. Dairy Sci. 102:3994-4001. https://doi.org/10 $.3168 /$ jds.2018-15847.

AOAC International. 1995. Official Methods of Analysis. 15th ed. AOAC International.

AOAC International. 1996. Official Methods of Analysis. 16th ed. AOAC International.

AOAC International. 2002. Official Methods of Analysis. 17th ed. AOAC International.

Araujo, G., C. Yunta, M. Terré, A. Mereu, I. Ipharraguerre, and A. Bach. 2015. Intestinal permeability and incidence of diarrhea in newborn calves. J. Dairy Sci. 98:7309-7317. https://doi.org/10 $.3168 /$ jds.2015-9666.

Arrieta, M. C., L. Bistritz, and J. B. Meddings. 2006. Alterations in intestinal permeability. Gut 55:1512-1520. https://doi.org/10 .1136 /gut.2005.085373.

Bernardini, D., G. Gerardi, A. Peli, L. Nanni Costa, M. Amadori, and S. Segato. 2012. The effects of different environmental conditions on thermoregulation and clinical and hematological variables in long-distance road-transported calves. J. Anim. Sci. 90:1183-1191. https://doi.org/10.2527/jas.2011-4113.

Bischoff, S. C., G. Barbara, W. Buurman, T. Ockhuizen, J. D. Schulzke, M. Serino, H. Tilg, A. Watson, and J. M. Wells. 2014. Intestinal permeability: A new target for disease prevention and therapy. BMC Gastroenterol. 14:189. https://doi.org/10.1186/s12876-014 -0189-7.

Bjarnason, I., A. Macpherson, and D. Hollander. 1995. Intestinal permeability: An overview. Gastroenterology 108:1566-1581. https:// doi.org/10.1016/0016-5085(95)90708-4.

Cernicchiaro, N., B. J. White, D. G. Renter, A. H. Babcock, L. Kelly, and R. Slattery. 2012. Associations between the distance traveled from sale barns to commercial feedlots in the United States and overall performance, risk of respiratory disease, and cumulative mortality in feeder cattle during 1997 to 2009. J. Anim. Sci. 90:1929-1939. https://doi.org/10.2527/jas.2011-4599.

Coleman, S. W., and B. C. Evans. 1986. Effects of nutrition, age and size on compensatory growth in two breeds of steers. J. Anim. Sci. 63:1968-1982. https://doi.org/10.2527/jas1986.6361968x.

Cooke, R. F. 2017. Invited paper: Nutritional and management considerations for beef cattle experiencing stress-induced inflammation. Prof. Anim. Sci. 33:1-11. https://doi.org/10.15232/pas.2016 $-01573$.

Cooke, R. F., T. A. Guarnieri Filho, B. I. Cappellozza, and D. W. Bohnert. 2013. Rest stops during road transport: Impact on performance and acute-phase protein responses of feeder cattle. J. Anim. Sci. 91:5448-5454. https://doi.org/10.2527/jas.2013-6357.

Deitch, E. A., J. Winterton, and R. Berg. 1987. Effect of starvation, malnutrition, and trauma on the gastrointestinal tract flora and bacterial translocation. Arch. Surg. 122:1019-1024. https://doi .org/10.1001/archsurg.1987.01400210057008.

European Council. 2005. European Council Regulation (EC) No 1/2005 of 22 December 2004 on the protection of animals during transport and related operations and amending Directives 64/432/ EEC and 93/119/EC and Regulation (EC) No 1255/97.

Ferraris, R. P., and H. V. Carey. 2000. Intestinal transport during fasting and malnutrition. Annu. Rev. Nutr. 20:195-219. https:// doi.org/10.1146/annurev.nutr.20.1.195.

Fragkos, K. C., and A. Forbes. 2018. Citrulline as a marker of intestinal function and absorption in clinical settings: A systematic review and meta-analysis. United European Gastroenterol. J. 6:181-191. https://doi.org/10.1177/2050640617737632.

Fröhli, D., and J. W. Blum. 1988. Effects of fasting on blood plasma levels, metabolism and metabolic effects of epinephrine and norepinephrine in steers. Eur. J. Endocrinol. 118:254-259. https://doi .org/10.1530/acta.0.1180254.

Gilani, S., G. S. Howarth, S. M. Kitessa, C. D. Tran, R. E. A. Forder, and R. J. Hughes. 2017. Intestinal permeability induced by lipopolysaccharide and measured by lactulose, rhamnose and mannitol sugars in chickens. Animal 11:1174-1179. https://doi.org/10.1017/ S1751731116002470.
González, L. A., K. S. Schwartzkopf-Genswein, M. Bryan, R. Silasi, and F. Brown. 2012. Factors affecting body weight loss during commercial long haul transport of cattle in North America. J. Anim. Sci. 90:3630-3639. https://doi.org/10.2527/jas.2011-4786.

Grigor, P. N., M. S. Cockram, W. B. Steele, C. J. Le Sueur, R. E. Forsyth, J. A. Guthrie, A. K. Johnson, V. Sandilands, H. W. Reid, C. Sinclair, and H. K. Brown. 2001. Effects of space allowance during transport and duration of mid-journey lairage period on the physiological, behavioural and immunological responses of young calves during and after transport. Anim. Sci. 73:341-360. https:// doi.org/10.1017/S135772980005832X.

Gultekin, M., H. Voyvoda, K. Ural, H. Erdogan, C. Balikci, and G. Gultekin. 2019. Plasma citrulline, arginine, nitric oxide, and blood ammonia levels in neonatal calves with acute diarrhea. J. Vet. Intern. Med. 33:987-998. https://doi.org/10.1111/jvim.15459.

Hall, E. J. 1999. Clinical laboratory evaluation of small intestinal function. Vet. Clin. North Am. Small Anim. Pract. 29:441-469. https: //doi.org/10.1016/S0195-5616(99)50030-2.

Herman, J. P., J. M. McKlveen, S. Ghosal, B. Kopp, A. Wulsin, R. Makinson, J. Scheimann, and B. Myers. 2016. Regulation of the hypothalamic-pituitary-adrenocortical stress response. Compr. Physiol. 6:603-621. https://doi.org/10.1002/cphy.c150015.

Horst, E. A., E. J. Mayorga, M. Al-Qaisi, S. Rodriguez-Jimenez, B. M. Goetz, M. A. Abeyta, P. J. Gorden, S. K. Kvidera, and L. H. Baumgard. 2020. Evaluating effects of zinc hydroxychloride on biomarkers of inflammation and intestinal integrity during feed restriction. J. Dairy Sci. 103:11911-11929. https://doi.org/10.3168/ jds.2020-18860.

Hunt, E., Q. Fu, M. U. Armstrong, D. K. Rennix, D. W. Webster, J. A. Galanko, W. Chen, E. M. Weaver, R. A. Argenzio, and J. M. Rhoads. 2002. Oral bovine serum concentrate improves cryptosporidial enteritis in calves. Pediatr. Res. 51:370-376. https://doi.org/ 10.1203/00006450-200203000-00017.

Hutcheson, D. P., and N. A. Cole. 1986. Management of transit-stress syndrome in cattle: Nutritional and environmental effects. J Anim. Sci. 62:555-560. https://doi.org/10.2527/jas1986.622555x.

Kim, Y. H., R. Nagata, N. Ohtani, T. Ichijo, K. Ikuta, and S. Sato. 2016. Effects of dietary forage and calf starter diet on ruminal $\mathrm{pH}$ and bacteria in Holstein calves during weaning transition. Front. Microbiol. 7:1575. https://doi.org/10.3389/fmicb.2016.01575.

Knowles, T. G., S. N. Brown, J. E. Edwards, A. J. Phillips, and P. D. Warriss. 1999. Effect on young calves of a one-hour feeding stop during a 19-hour road journey. Vet. Rec. 144:687-692. https://doi .org/10.1136/vr.144.25.687.

Knowles, T. G., P. D. Warriss, S. N. Brown, J. E. Edwards, P. E. Watkins, and A. J. Phillips. 1997. Effects on calves less than one month old of feeding or not feeding them during road transport of up to 24 hours. Vet. Rec. 140:116-124. https://doi.org/10.1136/ vr.140.5.116.

Kvidera, S. K., E. A. Horst, M. V. Sanz Fernandez, M. Abuajamieh, S. Ganesan, P. J. Gorden, H. B. Green, K. M. Schoenberg, W. E. Trout, A. F. Keating, and L. H. Baumgard. 2017. Characterizing effects of feed restriction and glucagon-like peptide 2 administration on biomarkers of inflammation and intestinal morphology. J. Dairy Sci. 100:9402-9417. https://doi.org/10.3168/jds.2017-13229.

Lambert, G. P. 2009. Stress-induced gastrointestinal barrier dysfunction and its inflammatory effects. J. Anim. Sci. 87(Suppl. 14):E101-E108. https://doi.org/10.2527/jas.2008-1339.

Loerch, S. C., and F. L. Fluharty. 1999. Physiological changes and digestive capabilities of newly received feedlot cattle. J. Anim. Sci. 77:1113-1119. https://doi.org/10.2527/1999.7751113x.

Marcato, F., H. van den Brand, B. Kemp, B. Engel, M. WolthuisFillerup, and K. van Reenen. 2020. Effects of pre-transport diet, transport duration, and type of vehicle on physiological status of young veal calves. J. Dairy Sci. 103:3505-3520. https://doi.org/10 $.3168 /$ jds.2019-17445.

Marcato, F., H. van den Brand, B. Kemp, and K. van Reenen. 2018 Evaluating potential biomarkers of health and performance in veal calves. Front. Vet. Sci. 5:133. https://doi.org/10.3389/fvets.2018 .00133 . 
Marques, R. S., R. F. Cooke, C. L. Francisco, and D. W. Bohnert. 2012. Effects of twenty-four hour transport or twenty-four hour feed and water deprivation on physiologic and performance responses of feeder cattle. J. Anim. Sci. 90:5040-5046. https://doi .org/10.2527/jas.2012-5425.

Marti, S., R. E. Wilde, D. Moya, C. E. M. Heuston, F. Brown, and K. S. Schwartzkopf-Genswein. 2017. Effect of rest stop duration during long-distance transport on welfare indicators in recently weaned beef calves. J. Anim. Sci. 95:636-644. https://doi.org/10 $.2527 /$ jas.2016.0739.

Moeser, A. J., L. B. Borst, B. L. Overman, and J. S. Pittman. 2012. Defects in small intestinal epithelial barrier function and morphology associated with peri-weaning failure to thrive syndrome (PFTS) in swine. Res. Vet. Sci. 93:975-982. https://doi.org/10 .1016/j.rvsc.2012.01.003.

Mormede, P., J. Soissons, R. M. Bluthe, J. Raoult, G. Legarff, D. Levieux, and R. Dantzer. 1982. Effect of transportation on blood serum composition, disease incidence, and production traits in young calves. Influence of the journey duration. Ann. Rech. Vet. $13: 369-384$.

Pardon, B., B. Catry, R. Boone, H. Theys, K. De Bleecker, J. Dewulf, and P. Deprez. 2014. Characteristics and challenges of the modern Belgian veal industry. Vlaams Diergeneeskd. Tijdschr. 83:155-163. https://doi.org/10.21825/vdt.v83i4.16641.

Pederzolli, R.-L. A., A. G. Van Kessel, J. Campbell, S. Hendrick, K. M. Wood, and G. B. Penner. 2018. Effect of ruminal acidosis and short-term low feed intake on indicators of gastrointestinal barrier function in Holstein steers. J. Anim. Sci. 96:108-125. https://doi .org/10.1093/jas/skx049.

Quigley, J. D. III, L. A. Caldwell, G. D. Sinks, and R. N. Heitmann. 1991. Changes in blood glucose, non-esterified fatty acids, and ketones in response to weaning and feed intake in young calves. J. Dairy Sci. 74:250-257. https://doi.org/10.3168/jds.S0022 -0302(91)78167-8.

Renaud, D. L., T. F. Duffield, S. J. LeBlanc, S. Ferguson, D. B. Haley, and D. F. Kelton. 2018. Risk factors associated with mortality at a milk-fed veal calf facility: A prospective cohort study. J. Dairy Sci. 101:2659-2668. https://doi.org/10.3168/jds.2017-13581.

Schumann, C. 2002. Medical, nutritional and technological properties of lactulose. An update. Eur. J. Nutr. 41:i17-i25. https://doi.org/ 10.1007/s00394-002-1103-6.

Tadich, N., C. Gallo, H. Bustamante, M. Schwerter, and G. van Schaik. 2005. Effects of transport and lairage time on some blood constituents of Friesian-cross steers in Chile. Livest. Prod. Sci. 93:223-233. https://doi.org/10.1016/j.livprodsci.2004.10.004.
Therkildsen, M. 2005. Muscle protein degradation in bull calves with compensatory growth. Livest. Prod. Sci. 98:205-218. https://doi .org/10.1016/j.livprodsci.2005.05.008.

Trunkfield, H. R., and D. M. Broom. 1990. The welfare of calves during handling and transport. Appl. Anim. Behav. Sci. 28:135-152. https://doi.org/10.1016/0168-1591(90)90050-N.

Vilela, E. G., H. O. G. Torres, M. L. A. Ferrari, A. S. Lima, and A. S. Cunha. 2008. Gut permeability to lactulose and mannitol differs in treated Crohn's disease and celiac disease patients and healthy subjects. Braz. J. Med. Biol. Res. 41:1105-1109. https://doi.org/ 10.1590/S0100-879X2008001200010.

von Borell, E. H. 2001. The biology of stress and its application to livestock housing and transportation assessment. J. Anim. Sci. 79(E-Suppl.):E260-E267. https://doi.org/10.2527/jas2001.79E -SupplE260x.

Wilms, J., H. Berends, and J. Martín-Tereso. 2019. Hypertonic milk replacers increase gastrointestinal permeability in healthy dairy calves. J. Dairy Sci. 102:1237-1246. https://doi.org/10.3168/jds .2018-15265.

Wilson, D. J., J. Stojkov, D. L. Renaud, and D. Fraser. 2020. Short communication: Condition of male dairy calves at auction markets. J. Dairy Sci. 103:8530-8534. https://doi.org/10.3168/jds .2019-17860.

Windmueller, H. G., and A. E. Spaeth. 1981. Source and fate of circulating citrulline. Am. J. Physiol. 241:E473-E480. https://doi.org/ 10.1152/ajpendo.1981.241.6.E473.

Wood, K. M., S. I. Palmer, M. A. Steele, J. A. Metcalf, and G. B. Penner. 2015. The influence of age and weaning on permeability of the gastrointestinal tract in Holstein bull calves. J. Dairy Sci. 98:7226-7237. https://doi.org/10.3168/jds.2015-9393.

Zhang, S., R. I. Albornoz, J. R. Aschenbach, D. R. Barreda, and G. B. Penner. 2013. Short-term feed restriction impairs the absorptive function of the reticulo-rumen and total tract barrier function in beef cattle. J. Anim. Sci. 91:1685-1695. https://doi.org/10.2527/ jas.2012-5669.

\section{ORCIDS}

L. Pisoni ํ https://orcid.org/0000-0001-7254-3395

M. Devant () https://orcid.org/0000-0001-8474-5058

M. Blanch $\odot$ https://orcid.org/0000-0001-9486-6152

J. J. Pastor (๑) https://orcid.org/0000-0003-2448-2334

S. Marti @ https://orcid.org/0000-0002-8115-0582 